\title{
HIV, Human Rights and Migration: Narratives of HIV-Positive Asylum Seekers in Scotland
}

\author{
George Palattiyil ${ }^{1}$ (I) Dina Sidhva²
}

Accepted: 10 February 2021 / Published online: 3 May 2021

(c) The Author(s) 2021

\begin{abstract}
Political instability, armed unrest, religious intolerance, human rights violations, ethnic conflict and environmental disasters that threaten one's life, displace people and often compel them to seek asylum elsewhere. Over the years, the UK has been a major recipient of asylum seekers, some of whom have come to Scotland, especially since 2000, and among these there are a number who present health issues including being HIV-positive. HIV-positive asylum seekers experience poverty, isolation, vulnerability, stigma and discrimination, which when coupled with a lack of appropriate medical care and support, have the potential of adding another layer on the denial of fundamental human rights and further stigmatising people who are already fleeing circumstances threatening their very existence. This paper discusses findings from a recent study that examined the lived experiences of HIV-positive asylum seekers since their arrival in Scotland. A flexible qualitative research design that included in-depth interviews that used life history and a phenomenological approach was adopted. Underpinned by ethics approval, nineteen HIV-positive Black African asylum seekers were recruited through third sector organisations in Glasgow, Scotland. Additional data were gathered from two emotive and discursive focus group meetings. Findings were developed using narrative analysis. The accounts of the asylum seekers reflect continued fear of stigma in the face of HIV disclosure, but also pervasive poverty and inequality. Their experiences include denial of rights to family and security, fear of being detained and deported, denial of appropriate medical care, symptoms of post-traumatic disorder and the culturally insensitive and sometimes inhumane attitude of the UK Immigration Agency. These themes depict an everyday struggle in a context of denial of support and risk of potential deportation to a country where HIV treatment is limited or inaccessible. Their narratives also attest to the life-giving, unstinting care and support they receive from a handful of voluntary agencies and one specialist HIV clinic in Scotland. The findings from this study raise issues for a debate about the treatment of HIVpositive asylum seekers in Scotland. Poverty, inequality, stigma and discrimination continue to pose difficulties in accessing care and treatment and wider community integration. Often treated in a piecemeal and 'service-siloed' fashion, the needs and human rights of HIV-positive asylum seekers require a greater, more holistic practice and policy attention.
\end{abstract}

Keywords HIV $\cdot$ Human rights $\cdot$ Migration $\cdot$ Vulnerability $\cdot$ Stigma and discrimination

\section{Introduction}

The connected global issues of state fragility and forced migration have recently assumed critical positions on the domestic and foreign policy platforms of several nations

George Palattiyil

g.palattiyil@ed.ac.uk

1 School of Social and Political Science, The University of Edinburgh, 15A George Square, Edinburgh EH8 9LD, UK

2 School of Education and Social Sciences, University of the West of Scotland, Room L226, Elles Building (East), Paisley Campus, Paisley PA1 2BE, UK
(Palattiyil \& Sidhva, 2017). Millions of people have been displaced due to war, conflict, poverty, political instability, human rights violations and environmental factors and find themselves living as forced migrants (Amnesty International, 2018; Human Rights Watch, 2015; Zetter, 2015).

The global population of forcibly displaced persons has increased substantially in the past two decades, rising from 37.3 million in 1996 to 79.6 million in 2020 (United Nations High Commission for Refugees, 2020; UNHCR, 2016). The number of refugees and internally displaced persons has reached unprecedented levels (IDMC \& NRC, 2016; UNHCR, 2018). By the end of 2019, the forcibly displaced people globally included 26 million refugees registered 
with the UNHCR, 4.2 million asylum seekers and 45.7 million internally displaced people (UNHCR, 2020).

Migration is a complex phenomenon (Leloup, 1996; Pria, 2012; European Commission, 2015); the continuing civil war in Syria and Iraq, collapse of government in Libya and other humanitarian crises in the Middle East, North and subSaharan Africa and Afghanistan are driving this new surge in migration (Gartenstein-Ross et al., 2015; United Nations, 2015; United Nations High Commission for Refugees, 2016; Human Rights Watch, 2015). Fleeing conflict, poverty, persecution, political repression and human rights violations (International Organisation for Migration, 2020; IOM, 2006), many migrants continue to make perilous journeys in their struggle for dignity and a decent life.

The United Kingdom (UK) has received a considerable number of asylum seekers during the past few years, although policies of successive governments have attempted to reduce the overall number (Palattiyil \& Sidhva, 2017). A report from the Office for National Statistics (2017) reveals that in the year ending March 2017, the Home Office received over 36,000 asylum applications, this was a $13 \%$ decrease compared with the year before and considerably less compared with the peak in 2002 which involved over 100,000 applications.

With the introduction of a dispersal policy by the UK Home Office in 2000 that sought to distribute asylum seekers throughout the UK, instead of a concentration in London (Creighton et al., 2004), many asylum seekers were relocated to Scotland. While data specific to Scotland are hard to come by, according to the Scottish Refugee Council, there were around 2400 asylum seekers that are living in Scotland in 2012 (Scottish Refugee Council, 2012). Another estimate by Haley (2013) indicates that a total of about 20,000 refugees, asylum seekers and other people of concern were living in Scotland in 2013, which makes up less than 0.5\% of the Scottish population. Of those who live in Scotland now, some are living with HIV (Palattiyil \& Sidhva, 2017). Specific numbers of asylum seekers living with HIV in Scotland are unknown, possibly because of the sometimes itinerant nature of the asylum-seeking population and the concern that disclosure might result in endangerment of their asylum claim. Health Protection Scotland report (2018) estimated that there were 5099 people living with HIV in Scotland; this includes asylum seekers and refugees who are mostly of sub-Saharan African origin, now living in Scotland. In the Scottish context, the highest prevalence of HIV in both sexes is among those who have risked exposure in sub-Saharan Africa; however, as indicated, the actual number of asylum seekers who are HIV-positive remains unclear (Palattiyil \& Sidhva, 2017).

Migration can often have serious health consequences for migrants (World Health Organisation, 2003) who in the context of this paper refers to refugees and asylum seekers, who are exposed to a multiplicity of risks and vulnerabilities; in addition to language, cultural, economic, and social barriers (Amon \& Todrys, 2009). They have historically faced extreme disparities in access to health care, living conditions, and treatment by the public (Palattiyil \& Sidhva, 2017; Chuah et al., 2018; Hynie, 2018; Rosenthal, 2018). Moreover, migrants are also likely to experience specific challenges influencing their health due to the migration process itself, commonly referred to as the social determinants of migrants' health (IOM, 2006).

Since the emergence of the HIV epidemic, migrant populations have received considerable recognition from the international community in the context of risk, transmission, and prevention of HIV (Wolffers et al., 2003; McGrath et al., 2015). The prevalence of HIV tends to be higher among migrants originating from countries where the primary contributor to the epidemic is heterosexual transmission (UNAIDS, 2014). Migrants may acquire HIV during transit or in the country of their destination. Given the uncertainty about their immigration status, they often find themselves unable to access health and social care services appropriately. Additionally, they face denial, discrimination, detention, and deportation (Human Rights Watch, 2009) by the immigration authorities of the host country, all of which intensify their risk and vulnerability to HIV. Social exclusion also leaves migrants highly vulnerable to HIV (UNAIDS, 2014). According to an EU report, nearly four out of every ten people with HIV in the European Economic Area is a migrant to the country in which they are diagnosed (NAMAIDS Map, 2015); this indeed paints a poignant picture of the link between migration and HIV (Martinez-Donate et al., 2015). The instability and destitution many experience upon entering a new country heighten risks and increase their vulnerability (Palattiyil \& Sidhva, 2017).

HIV disproportionately affects marginalised groups such as asylum seekers and refugees, and the risk of HIV transmission is known to be greater in situations of poverty and inequality (Cherfas, 2006). Large numbers of asylum seekers travel from poorer countries where there is a high prevalence of HIV, and they also have individual experiences of persecution, conflict, and human rights violations. Consequently, they are at a greater risk of contracting HIV. Many asylum seekers are fleeing areas where there are few legal protections of individual rights and where conflict, violence, and abuse are all too commonplace. It is obvious that the very issues that compel people to seek asylum are the ones that drive the HIV epidemic and make asylum seekers particularly vulnerable to HIV (Haour-Knipe, 2003).

HIV thrives in conditions of poverty, conflict and inadequate living conditions (Davies, 2006; Spiegal \& Nankoe, 2004). The lives of asylum seekers are characterised by these issues, making them more susceptible to the disease, as they are often placed in positions of powerlessness. 
HIV-positive asylum seekers experience poverty, isolation, vulnerability, stigma and discrimination, which when coupled with a lack of support and access to appropriate medical care have the potential of denying fundamental human rights and dehumanising people who are already fleeing circumstances threatening their very existence.

Although the UK is signatory to the European Convention of Human Rights (ECHR) and the 1951 Refugee Convention, difficulties arise in how member states use their legal powers to interpret human rights, as many of the underpinning principles are not legally binding. For instance, in 2005, the House of Lords ruled that failed asylum seekers with HIV do not have the right to stay in the UK to receive treatment and that deportation would not constitute a breach of Article 3 of the ECHR (Davies, 2006). Thus, despite the protection afforded by international human right laws, a narrow interpretation can result in many people being denied these rights. Accordingly, many asylum seekers continue to be directly discriminated against, particularly HIV-positive asylum seekers (Davies, 2006; Palattiyil \& Sidhva, 2015, 2017). Ironically, the 2005 ruling was judged on the premise that the person was not at a 'terminal stage' of illness; however, the person's state of health was due to the HIV treatment accessed within the UK (Bettinson \& Jones, 2007).

Current research on the experiences of HIV-positive asylum seekers in Scotland is relatively limited and those living with HIV are a truly hidden population (Palattiyil \& Sidhva, 2015, 2017); even an invitation to participate in research is often met with reluctance owing to the fear of being exposed as HIV-positive and resultant stigma. Against this backdrop, this paper aims to explore the lived experiences of asylum seekers, living with HIV in Scotland, seen through the lens of human rights.

\section{Methods}

Qualitative methodology was used to explore the experiences of HIV-positive asylum seekers living in Scotland. Researching vulnerable, hard-to-reach population such as HIV-positive asylum seekers brings a number of complexities, challenges and dilemmas to the fore. Many HIV-positive asylum seekers-and in particular those whose applications have been refused-are often unwilling to engage with people outside of their known support systems.

Given the sensitivity of the study, identifying participants was complex, challenging and time consuming. Several voluntary agencies in Scotland that worked with people living with HIV were approached, although the large majority of the sample came from one agency in Glasgowthe Waverley Care's African Health Project, which provides support to people living with HIV.
The study drew on convenience sampling-nineteen Black African asylum seekers living with HIV (15 women and 4 men) took part in the study. Participants hailed from varied nationalities - from Zimbabwe, Ivory Coast, Burundi, Ethiopia, Malawi, South Africa, Nigeria, Tanzania, Uganda, and Kenya. Fieldwork for data collection was complex, often fraught with uncertainties that mark the lives of the asylum seekers, with interviews often canceled at very short notice.

Open-ended in-depth interviews and two focus groups were held with the participants, generally in the premise of the African Health Project. A few interviews were held in unconventional venues, such as a café or the researcher's automobile, where the participants felt safer. All interviews were audio-recorded with the prior consent of the participants and some of the interviews extended over multiple sessions as the participants wanted time to tell their stories.

Central to the research were the critical issues of informed consent, confidentiality, voluntary participation and anonymity. Prior ethical approval was obtained from the institutional ethics committee. Participants were assured that they could discontinue the interview at any point that they felt necessary and that they were not obliged to answer anything they felt uncomfortable with or did not choose to answer. There were a few occasions where participants felt overtaken by their emotions and the researcher had to discontinue the interviews immediately. After a pause, and in discussion with the participants, these interviews were resumed, with a few of them being rescheduled to another date. In situations of distress, participants were also signposted to additional support that the agency provided. It was evident from the outset of the study how difficult it was to gain access to this otherwise very hard-to-reach population, as some of the failed asylum seekers lived essentially as fugitives, fearing deportation. Therefore, ensuring anonymity and protecting the identity of the participants were central to the research process.

Analysis began with the transcription of interviews. Narrative analysis (Riessman, 1993) was used to explore the participants' everyday experiences and the way they perceived the world. Each transcript was read and analysed for content; these were then classified into categories that recurred across participant accounts or were unique to a particular participant's account. These categories were then developed into themes that provide a window into the lived experiences of the participants.

\section{Results}

Through the individual interviews and focus group discussions, asylum seekers were encouraged to explore their migration journeys and their wider experiences of life 
in Scotland. While several themes emerged, this paper will focus on three key issues - the reasons for migration, their views and experiences of human rights while living with HIV, and of seeking care and treatment in Scotland.

A significant number of the respondents left their country on account of the violence they or their close family members had experienced. The violence described by the respondents fell into two categories: (1) state-sponsored violence or (2) violence in a personal relationship. One woman from Zimbabwe described her situation: "I came for my safety because Zimbabwe was politically very unstable...I was in danger of becoming a victim of violence...I saw people being beaten, people disappearing...one day they came for me...I was scared and terrified, that's when I decided that I needed a way out". Another woman from Uganda, whose father and brother had been vocal against the ruling regime, left her 2 young children with a friend because her father had disappeared and her brother had been murdered in front of her. She said: "I left to save my life ... I thought if I am to survive I will need to run away for my safety". Yet, another woman spoke about the continuing horror and nightmare that she has lived through for almost a decade after she was raped in front of her son by the supporters of the ruling party, which she did not support. She spoke about the humiliation and pain of being gang-raped in front of an adult son and how that gave her the strength to flee her country. She said: "Back home there was violence between parties just before the elections and I was at home with my big son and they just came into my home and raped me in front of my son, so I decide to run away from my country... oh it was a terrible experience...my big son tried to protect me, but he was beaten when he was trying to help me ...". Others spoke about the gender-based violence that forced them to leave their homes and seek asylum in the UK. They recalled of being abused just because they were women: being beaten by their husbands or partners, being raped with impunity and being ritually mutilated. One woman from Malawi spoke about the constant abuse and violence she experienced from her husband because she did not get pregnant. She said, "Things became so bad one day that he chased me out of the house naked. My Pastor brought me to here on a visitor's visa to get a break ...but I decided never to go back there, because I could not go back to that living hell...I would rather live here with all the problems than go home to him".

Reflecting on their experiences of life in Scotland, respondents were rather vocal and wanting to have their voices heard, particularly when talking about their experiences of care and treatment-they spoke highly of a specialist HIV clinic in Glasgow: "people at the Brownlee clinic are all caring and sympathetic...their support really touches you here (pointing to her heart) and makes you feel that people care, that you matter as an individual". Similar sentiments were echoed when describing the African Health Project (a non-profit organisation in Glasgow), their main drop-in centre. However, a majority of them were unhappy with the treatment received from more mainstream public health services such as their General Practitioners (GP), dentists, NHS24, A\&E and Ambulance Service. One women said: "It's quite different going to see my GP...I have a problem with my blood pressure and he puts on gloves to check my blood pressure...I perceive a sense of discrimination". One man pointed out: "I see different GPs each time...they asked me what my condition is...so I told her about fungal infections and she asked me "why did you not tell me you are HIV'. And I said you have my records in front of you...I don't want to be reminded all the time about my status; HIV is not my second name".

Another woman spoke about her experience of discrimination in her dental practice; she said: "I don't go to the dentist...the nurses are very rude...the file has HIV written in bold letters on top, so you have no privacy".

Some respondents were visibly upset when speaking about some of their experiences in relation to seeking asylum. Interestingly, several respondents used metaphors from nature such as "the edge of a mountain, a dark tunnel, a deep well and shifting sands". One man told the interviewer that he found it difficult to sleep and to eat and that he felt as though he was living on the edge of a cliff. He explained: "It is a very difficult time for me; I feel every time worry and thinking all the time; cannot stop thinking, this and that. I am worrying about me, what about my life in this country, what about me? What the Home Office is going to do with me; how is my future going to be? As if I am at the end of a high mountain and can be fallen down at any moment". One woman described the process of asylumseeking as a dark, interminable tunnel with little hope and a sense of pervasive uncertainty. She said rather poignantly: "It's like you have to just keep travelling in the dark...you can't turn back because that is gone too far. There is no place to get off right or left and you don't see no lights at the end of the tunnel, but you just have to think that your day will come, when you get out of this tunnel which is being an asylum seeker here". Another woman likened the asylum seeking process to being in a deep well. She said: "You are there not because you wanted to be, but because you had to be ...you are trying to get someone to save you, but they don't even want to hear your cries...they think somehow you deserve to be there. What else can we feel scared about every minute in the present and not knowing, not knowing what the morning will bring and will it come for me?" One woman asked the researcher if she had heard of the shifting sands in Tanzania. She likened the asylum process to the shifting sands that kept blowing you "further and further, but you don't know when you're going to be able to settle down". 
Dealing with the difficulties of having a HIV diagnosis, at the same time as trying to cope with various issues involved with the asylum process clearly places HIVpositive asylum seekers in a position of double jeopardy. One woman said that had she only been HIV-positive, she would have managed to deal with it more resolutely, but being an asylum-seeker meant that she could be returned home and if that were to happen, it would mean death on both counts. She said: "The most painful thing is the thought that you might be sent back to your country, where you will definitely die because they will find you and they will make sure you die and even if you are saved from them HIV will kill you". Another woman said that her position was not one of 'double jeopardy' but one of 'multiple jeopardy'. She said: "I have so many problems, I ask myself so many questions ... It is just because I am black? Is it just because I am a woman? Is it just because I am HIV? Is it just because I am an asylum seeker?".

Participants also narrated their experiences of being detained in a detention centre where they were unable to follow the HIV medication regimen. One participant recounted that he was meant to take medication with specifically prepared meals, yet the routine at detention centres made this problematic. He likened the detention centre to a glorified prison. He said: "It's more like a fancy prison, but you sleep in dormitories. I was unable to manage my treatment there. I was really so wretched and sad. People go around like zombies. Only the doctor can stop and start your medication but they just take you and they don't care; if you have to start and how bad you feel".

Nowhere were their narratives as poignant as in their perception and experience of human rights while they eked out a living in Scotland. An emotionally charged thought from a Zimbabwean woman encapsulates the wider feeling. She said:

"We have come to a country who criticises Zimbabwe for not having human rights, for not taking human rights in to consideration. Where are the human rights where we have come to seek asylum, where we have come to look for hope that we might lead a better life? Where is it when we are watching our own fellow friends being denied asylum, being refused anywhere to stay, even if we have been given a house we cannot even house them because the law states you cannot accommodate another? Where are the human rights in that? Can you tell us 'where are the human rights'? You are supposed to be secure, because we can't feel it. You are supposed to be kind to people like us in our condition. We came here in the hope, in the hope for a better life. When we are HIV positive, for a much longer life... where is it? For a much better life, where is it? Where is it when we are stressed, even when we are on medication, where is it? Oh please give us some hope, show us that you have got human rights, show us that much. Don't be hypocrites like the people we have run away from".

The narratives of asylum seekers in this study bear evidence to the difficult relationship between HIV, human rights and migration, particularly with vulnerability - both past and present. In many senses, it would appear that these asylum seekers have moved from one set of vulnerabilities to another, with considerable impact on their human rights.

\section{Discussion}

The narratives of HIV-positive asylum seekers in this study bear out the deep and complex relationship between HIV and human rights. Despite the advances in care and treatment of people living with the illness, HIV continues to be a major social and public health concern across the world, shining a glaring light on the human rights of those affected by the virus, especially in relation to access to health care.

Marginalised and vulnerable people such as women, children and in particular asylum seekers continue to face discrimination. Vulnerability to HIV infection feeds on violations of human rights, including discrimination against women, as well as conditions that create and sustain poverty. Given the importance of human rights in HIV prevention and treatment (UNAIDS, 2019), the international human rights system has explicitly recognised HIV status as a prohibited reason for discrimination. Either through legislation or litigation, many countries have recognised that their people have the right to HIV treatment as a part of their human rights, confirming that economic, social and cultural rights are justiciable (UNAIDS, 2006).

The International Guidelines on HIV/AIDS and Human Rights (UNAIDS, 2006) stressed that: "States should enact or strengthen anti-discrimination and other protective laws that protect vulnerable groups, people living with HIV and people with disabilities from discrimination in both the public and private sectors, ensure privacy and confidentiality and ethics in research involving human subjects, emphasize education and conciliation, and provide for speedy and effective administrative and civil remedies" (Guideline 5). Guideline 8 also calls on States to 'promote a supportive and enabling environment' for women, children and other vulnerable groups. The guideline calls upon the States to deal with prejudice and inequality through community dialogue and to create specially designed social and health services and support to these vulnerable community groups. The accounts of all the respondents in this study bear evidence of discrimination and lack of protection they have encountered as they make their lives in the UK. 
The UK Human Rights Act (1998) guarantees to protect the rights enshrined in the European Convention of Human Rights. However, the accounts of the asylum seekers illustrate several instances where their human rights have been breached. Several of the asylum seekers in the study reported being detained and removed to a detention centre without prior warning, and many reported that they have had to go with the immigration officials to the detention centre without having collected their medication from their place of stay. Such instances have had a significant impact on their ability to comply with medication. Similarly, those asylum seekers whose claims and appeals have been rejected usually had their State Support (Sect. 4 payments) discontinued 4 weeks after the decision. Once the State Support was cut, these asylum seekers were left with no money to buy food, and many faced destitution. Without proper food and accommodation, these HIV-positive asylum seekers found it very hard to follow the HIV treatment. The stories of the asylum seekers in this study presented many instances of discrimination and denial of human rights.

Respect for human rights is essential for effective responses to HIV/AIDS (Office of the United Nations High Commissioner for Human Rights, 2020), as infringements of human rights lie at the heart of marginalisation and the creation and continuation of vulnerability (Enoch \& Piot, 2017; UNAIDS, 2019). Regardless of one's immigration status, a rights-based approach is critical for people living with HIV so that they can continue to access HIV care and treatment and enjoy basic human rights.

Many HIV-positive asylum seekers were forced to make difficult choices about staying in the UK to access treatment or return to their country of origin, where an early death is more likely, a theme that echoed in the findings of Sinyemu and Baillie (2005). Many participants in the study reported the UK's position on the availability and accessibility of HIV prevention, care and treatment in their home country, notwithstanding the other critical factors that would increase their vulnerability if they are deported. For example, all asylum seekers living with HIV in this study had faced significant housing and financial difficulties, stigma and discrimination, with some assuming the role of a fugitive because they had no place to stay. Indeed, The Guardian's report "UK asylum seekers living in 'squalid, unsafe slum conditions" (2017) portrays a vivid picture of their sufferings. Such exposure increases their vulnerability and ability to cope with the illness and denies them their fundamental human rights. The narratives of HIV-positive asylum seekers in this study clearly portrayed a life that is "profoundly degrading and dehumanising" (Sinyemu \& Baillie, 2005, p. 33); an experience that runs contrary to article 3 and article 8 of the European Convention of Human Rights (Aspinall \& Watters, 2010).
Driven by an ever-powerful right-wing rhetoric, migrants have been described as the 'most demonised groups of people living in the Western world' (Phillimore, 2011). Newspaper portrayals such as 'Aids-infected asylum seekers overwhelm UK hospitals' (The Telegraph, 2003) do little to engender a more welcoming atmosphere. Instead, such rhetoric leads to increased stigma and hostility, restrictions on access to services and often punitive immigration controls, particularly affecting those living with HIV. Migrants' health status is often given little importance in the asylum process and those living with complex conditions such as HIV, feel doubly burdened (Soomre, 2008). Migration and HIV remain two of the largest social issues within the globalised world today (Davies, 2006; Martinez-Donate et al., 2015; McGrath et al., 2015) and HIV-positive migrants feel socially alienated, marginalised from resources, denied a number of basic human rights, while coping with a life-threatening illness (Ndirangu \& Evans, 2009).

Dealing with the difficulties of having an HIV diagnosis, at the same time as trying to cope with the complexities of seeking asylum places HIV-positive migrants in a position of double jeopardy. A few participants described this as "double trouble", while others felt their position was not one of 'double trouble' but one of 'multiple trouble'. As echoed in the findings, one of them said: "I have so many problems, I ask myself so many questions ... It is just because I am black? Is it just because I am a woman? Is it just because I am HIV? Is it just because I am an asylum seeker? In many ways, they feel sucked into a whirlpool of "multiple jeopardy" (Palattiyil \& Sidhva, 2015) as they went about their lives in Scotland.

The context of stigma and discrimination, fear of deportation and denial of basic human rights created a deep sense of alienation for many participants in this study; particularly for some who lived like a 'fugitive', moving from one place to another for fear of being detained. Nevertheless, all participants found the African Health Project, a specialist service for asylum seekers and refugees living with HIV, offering solace, and as a place to meet others experiencing similar conditions. Indeed, the staff at the HIV clinic were seen as a great source of help and advice—once contact had been established, they seemed satisfied with the care and support received, even praising some consultants for writing to the UK Home Office on their behalf. However, this could not be said of other health care professionals, who seemed less sympathetic in appreciating the complexities experienced by people fleeing persecution and how these impact on their ability to be open about their HIV status at the outset. The impact of their experiences of having a life-threatening illness and having to seek assistance as a vulnerable escapee from repressive conditions is a harsh reality (Palattiyil \& Sidhva, 2017) for many migrants; however, a major concern is the lack of cultural sensitivity (Alvarez-del Arco et al., 2013) to their unique set of circumstances. 


\section{Conclusion}

The recent past has seen a powerful negative and hostile rhetoric driving the asylum and immigration discourse in the UK (Hayes, 2013) — that places asylum seekers living with HIV at increased vulnerability and impacting their human rights (Palattiyil \& Sidhva, 2017). Whatever their reasons for travel, asylum seekers often find themselves separated from their immediate family members and familiar circumstances. They encounter language barriers, substandard living conditions, exploitative working practices and a lack of access to health and social care and social security benefits (UNAIDS, 2014).

Nearly four decades into the epidemic, HIV continues to be a complex issue globally, causing public health concerns and social problems. While advances in treatment and care have enabled many individuals living with HIV to live longer, there is compelling evidence of the impact of HIVassociated stigma and discrimination marginalising them and their families. Stories from around the world demonstrate the pervasiveness of this stigma, leading to a denial of basic human and civil rights (Palattiyil \& Sidhva, 2017).

Providing treatment to people living with HIV brings economic gains to society through a person's improved health and productivity. It also has a preventive effect by reducing the individual's viral load, thereby reducing the likelihood of transmitting the virus. Coupled with the falling costs for treatment, it is increasingly difficult to argue that people living with HIV incur greater costs to the destination country compared to the benefits they could contribute over a longterm stay while they are healthy (UNAIDS, 2014). While the recent changes have enabled asylum seekers in the UK to access HIV care and treatment at no extra cost, a cultural change is needed to address the underlying stigma and discrimination that surround those migrants living with HIV. An evidenceinformed debate about the contribution of migrants to the wider economy needs to be complemented by heightened awareness of the impact of stigma on marginalised communities. Collective efforts in embedding rights-based approaches to HIV care and treatment, irrespective of one's immigration status, are vital in shifting societal attitudes towards migrants.

Working with HIV-positive asylum seekers requires a high degree of specialist knowledge, practice and skills (Williams \& Graham, 2014). Practices should be underpinned by cultural competence that enables the practitioners to have a greater understanding of the culture of the country of origin, of the circumstances leading to departure and of the migration experiences (Segal, 2011; Palattiyil \& Sidhva, 2015). Third sector organisations with specialist knowledge of supporting migrants living with HIV can play a crucial role in strengthening the workforce skills and knowledge and ushering in culturally appropriate practices.
The narratives of HIV-positive asylum seekers in this study provide a painful glimpse of their lived experiences as they journeyed from their own countries to a country they call 'home' today. These themes portray their vulnerabilities, struggle and risks to personal safety, juxtaposed against the backdrop of denial of support and potential deportation (Palattiyil \& Sidhva, 2017).

The human rights of asylum seekers living with HIV have received increased policy attention in the past few years, because the human rights of persons living with HIV transcend nations and borders, and the realisation of their rights and fundamental freedoms is vital in reducing vulnerability to HIV (UNAIDS, 2006). There is an increasing commitment for human rights to take centre stage in the care and prevention of HIV globally which was underscored with the "Declaration of the Human Rights and HIV/AIDS: Now More than Ever" at the 2008 International AIDS Conference in Mexico City. If we are to achieve zero new HIV infections, zero discrimination, zero AIDS-related deaths (UNAIDS, 2010), then we need a concerted global response underpinned by political will, strategic partnerships and commitment to human rights of all.

In his article Refugees and Human Rights, Harvey (2015) argues that whatever the profound flaws of existing refugee and asylum law in the UK, one major challenge is to ensure that the positive aspects are properly, consistently, fairly and humanely applied in practice. There is a need to insist that the rule of law, human rights, and the principle of legality apply equally to refugees and asylum seekers.

This study has uncovered the plight of asylum seekers living with HIV as they try to establish new lives for themselves in the UK. It is hoped that these findings will help provide a voice for these individuals; that a new day is dawned for them, as evinced in one of the participant's evocative thought: "I like using my head, I like using my brain, I feel I am just sitting like a cabbage. I am scared every day, every single day. I dream of freedom, to be able to live freely without any fear. Britain can help us, let them show the world that they believe in the human rights that they speak about" (from a Zimbabwean woman respondent in the study).

Acknowledgements Dr Gary Clapton, Senior Lecturer in Social Work, School of Social and Political Science, University of Edinburgh for his critical comments on the draft manuscript.

Funding This research was funded by the British Academy Grant Number: SG-52166.

Open Access This article is licensed under a Creative Commons Attribution 4.0 International License, which permits use, sharing, adaptation, distribution and reproduction in any medium or format, as long 
as you give appropriate credit to the original author(s) and the source, provide a link to the Creative Commons licence, and indicate if changes were made. The images or other third party material in this article are included in the article's Creative Commons licence, unless indicated otherwise in a credit line to the material. If material is not included in the article's Creative Commons licence and your intended use is not permitted by statutory regulation or exceeds the permitted use, you will need to obtain permission directly from the copyright holder. To view a copy of this licence, visit http://creativecommons.org/licenses/by/4.0/.

\section{References}

Alvarez-del Arco, D., Monge, S., Azcoaga, A., Rio, I., Hernando, V., Gonzalez, C., et al. (2013). HIV testing and counselling for migrant populations living in high-income countries: A systematic review. European Journal of Public Health, 23(6), 1039-1045. https://doi.org/10.1093/eurpub/cks130.

Amnesty International. (2018). The state of the world's human rights: Amnesty International Report, 2017/18. Available at: https:// www.amnesty.org/en/documents/pol10/6700/2018/en/. Accessed 2 May 2020.

Amon, J., \& Todrys, K. (2009). Access to antiretroviral treatment for migrant populations in the Global South. International Journal on Human Rights, 10, 155-176.

Aspinall, P. \& Watters, C. (2010). Refugees and asylum seekers: A review from an equality and human rights perspective. Equality and Human Rights Commission, Research Report 52, University of Kent, Kent, UK.

Bettinson, V., \& Jones, A. (2007). The future of claims to resist removal by non-nationals suffering from HIV/AIDS. Liverpool Law Review, 28(2), 183-213.

Cherfas, L. (2006). Negotiating access and culture: Organizational responses to the healthcare needs of refugees and asylum seekers living with HIV in the UK. Oxford, UK: Refugee Studies Centre, University of Oxford.

Chuah, F. L. H., Tan, S. T., Yeo, J., \& Legido-Quigley, H. (2018). The health needs and access barriers among refugees and asylumseekers in Malaysia: A qualitative study. International journal for equity in health, 17, 120.

Creighton, S., Sethi, G., Edwards, S. G., \& Miller, R. (2004). Dispersal of HIV positive asylum seekers: National survey of UK healthcare providers. British Medical Journal, 329, 322-323. https://doi.org/ 10.1136/bmj.38189.674213.79.

Davies, R. (2006). A critical analysis of the right to health of failed asylum seekers and illegal migrants living with HIV and AIDS. Gender: Sexuality and Human Rights Law, Keele University, Keele, UK.

Enoch, J., \& Piot, P. (2017). Human rights in the fourth decade of the HIV/AIDS response: An inspiring legacy and urgent imperative. Health and human rights, 19(2), 117-122.

European Commission. (2015). European Commission - Fact Sheet. Available at: http://europa.eu/rapid/press-release_MEMO-154957_en.htm. Accessed 25 April 2020.

Gartenstein-Ross, D., Barr, N., Willcoxon, G., \& Basuni, N. (2015). The crisis in North Africa: Implications for Europe and options for EU policymakers. Netherlands Institute of International Relations Clingendael. Available at: http://www.clingendael.nl/sites/default/ files/The\%20crisis\%20in\%20North\%20Africa\%20report\%202015. pdf. Accessed 25 March 2020.

Haley, R. (2013). Asylum, Scotland and Independence - Scotland against Criminalising Communities. Available at http://www. sacc.org.uk/articles/2013/asylum-scotland-and-independence. Accessed 25 March 2020.

Haour-Knipe, M. (2003). Oral evidence presented in the All-Party Parliamentary Group on AIDS and APPG Refugees Parliamentary
Hearings, May 6 2003. Cited in All-Party Parliamentary Group on AIDS Migration and HIV: Improving Lives in Britain, London, UK.

Harvey, C. (2015). Refugees and Human Rights: The Future of International Protection in the UK. European Human Rights Law Review, 595-603.

Hayes, D. (2013). Modern Migration and the Creation of the Refugee. In M. Davies (Ed.), The Blackwell Companion to Social Work (pp. 215-220). Chichester: Wiley-Blackwell.

Health Protection Scotland. (2018). HIV infection in Scotland: Quarterly report to 31 December 2017. NHS Scotland. Glasgow. Calculations based on number of diagnosed individuals in Scotland. Available at: https://www.hps.scot.nhs.uk/publications/hps-weekly-report/ volume-52/issue-17/publication-of-hiv-infection-in-scotlandquarterly-report-to-31-december-2017/. Accessed 4 May 2020

Human Rights Watch. (2009). Discrimination, Denial, and Deportation: Human Rights Abuses Affecting Migrants Living with HIV. New York: Human Rights Watch.

Human Rights Watch. (2015). The Mediterranean migration crisis: Why people flee, what the EU should do. Available at: http:// www.hrw.org/sites/default/files/reports/eu0615_web.pdf. Accessed 5 April 2020.

Hynie, M. (2018). The Social Determinants of Refugee Mental Health in the Post-Migration Context: A Critical Review. Canadian journal of psychiatry. Revue canadienne de psychiatrie, 63, 297-303.

IDMC. (2016). GRID 2016 - Global Report on Internal Displacement. Internal Displacement Monitoring Centre and Norwegian Refugee Council. Available at: https://www.internal-displacement.org/ globalreport2016/2016/. Accessed 25 April 2020

International Organisation for Migration. (2006). Migration: A Social Determinant of the Health of Migrants. Geneva: Author.

International Organisation for Migration. (2020). Migration Initiatives 2020. Available at: https://publications.iom.int/system/files/pdf/ mi_2020.pdf. Accessed 5 May 2020.

Leloup, F. (1996). Migration, a complex phenomenon. International Journal of Anthropology, 11(2-4), 101-115.

Martinez-Donate, A. P., Hovell, M. F., Rangel, M. G., Zhang, X., Sipan, C. L., Magis-Rodriguez, C., \& Gonzalez-Fagoaga, J. E. (2015). Migrants in transit: The importance of monitoring HIV risk among migrant flows at the Mexico-US border. American journal of public health, 105(3), 497-509. https://doi.org/10.2105/ AJPH.2014.302336.

McGrath, N., Eaton, J., Marie-Louise Newell, ML., and Hosegood, V. (2015). Migration, sexual behaviour, and HIV risk: A general population cohort in rural South Africa. The Lancet HIV, 2(6), E252-E259. https://doi.org/10.1016/S2352-3018(15)00045-4

NAM AIDS Map. (2015). Four in ten people diagnosed with HIV in Europe are migrants. Available at: http://www.aidsmap.com/Fourin-ten-people-diagnosed-with-HIV-in-Europe-are-migrants/page/ 2978799/. Accessed 5 May 2020.

Ndirangu, E. W., \& Evans, C. (2009). 'Experiences of African immigrant women living with HIV in the U.K: Implications for health professionals. Journal of Immigrant Minority Health, 11, 108-114.

Office of the United Nations High Commissioner for Human Rights (2020). HIV/AIDS and Human Rights. Available at: https://www. ohchr.org/EN/Issues/HIV/Pages/HIVIndex.aspx. Accessed 7 May 2020.

Office for National Statistics. (2017) Migration Statistics Quarterly Report: May 2017. Available at: https://www.ons.gov.uk/ peoplepopulationandcommunity/population andmigration/ internationalmigration/bulletins/migrationstatisticsquarterlyreport/ may20172017. Accessed 16 April 2020.

Palattiyil, G., \& Sidhva, D. (2015). Caught in a web of double jeopardy-post-traumatic stress disorder and HIV positive Asylum seekers in Scotland. Clinical Social Work Journal, 43, 2. https://doi.org/10.1007/s10615-015-0542-5. 
Palattiyil, G., \& Sidhva, D. (2017). Listening to the voiceless: Lived experiences of asylum seekers living with HIV in Scotland and the implications for social work practice. In: Henrickson, M., Chipanta, D., Lynch, V., Muñoz Sanchez, H., Nadkarni, V., Semigina, T., \& Sewpaul, V. (Eds.). (2017). Getting to zero: Global social work responds to HIV. Geneva: UNAIDS and IASSW. (ISBN 978-0-9941415-4-5).

Phillimore, J. (2011). Approaches to health provision in the age of super-diversity: Accessing the NHS in Britain's most diverse city. Critical Social Policy, 31(1), 5-29.

Pria, A. (2012). Speech of the Head of Department for Immigration and Asylum, Department of Immigration and Civil Liberties, Ministry of the Interior, Italy; IOM International Dialogue on Migration, 13-14 September. Available at: https://www.iom.int/files/live/sites/iom/files/ What-We-Do/idm/workshops/protecting-migrants-during-times-ofcrisis-2012/speeches-presentations/Session_1_Angela-Pria.pdf20 12/speeches-presentations/Session_1_Angela-Pria.pdf. Accessed 20 April 2020.

Riessman, C. K. (1993). Narrative analysis. Newbury Park, CA: Sage. Scottish Refugee Council. (2012). Trapped: Destitution and Asylum in Scotland. Available at: https://www.scottishrefugeecouncil.org.uk/ wp-content/uploads/2019/10/Trapped-Destitution-and-asylum-inScotland-PDF.pdf2019/10/Trapped-Destitution-and-asylum-inScotland-PDF.pdf. Accessed 20 May 2020.

Rosenthal, T. (2018). Immigration and acculturation: Impact on health and well-being of immigrants. Current Hypertension Reports, 20, 70.

Segal, U. A. (2011). Work with Immigrants and Refugees. In: Healy, L.M. \& Link, R.J (eds) Handbook of International Social Work: Human Rights, Development, and the Global Profession. New York: Oxford University Press Inc. pp. 73-80.

Sinyemu, E., \& Baillie, M. (2005). HIV becomes your name: A report on the issues facing Africans living in Scotland who are HIV positive. Edinburgh, Scotland: Waverley Care.

Soomre, E. (2008). HIV and asylum, African HIV Policy Network. Available at: https://www.theguardian.com/uk/2008/aug/27/ immigration.hiv. Accessed 15 October 2017

Spiegal, P. B., \& Nankoe, A. (2004). UNHCR, HIV/AIDS and refugees: Lessons learned. Forced Migration Review, 19, 22-23.

The Guardian. (2017). UK asylum seekers living in 'squalid, unsafe slum conditions'. Available at: https://www.theguardian.com/uk-news/ 2017/oct/27/uk-asylum-seekers-living-in-squalid-unsafe-slumconditions?CMP=Share_AndroidApp_Gmail. Accessed 2 May 2020.

The Telegraph. (2003). Aids-infected asylum seekers 'overwhelm UK hospitals. Available at: http://www.telegraph.co.uk/news/uknews/
1433043/Aids-infected-asylum-seekers-overwhelm-UK-hospitals. html. Accessed 8 May 2020.

UK Human Rights Act (1998). Human Rights Act 1998. Available at: https://www.legislation.gov.uk/ukpga/1998/42. Accessed 26 February 2021.

UNAIDS. (2006). International Guidelines on HIV/AIDS and Human Rights. Geneva: Author.

UNAIDS. (2010). Global Report: UNAIDS Report on the Global AIDS Epidemic 2010. Geneva: Author.

UNAIDS. (2014). The Gap Report 2014 - Migrants. Available at http:// www.unaids.org/sites/default/files/media_asset/04_Migrants.pdf. Accessed 5 May 2020.

UNAIDS. (2019). UNAIDS Executive Director's message on the occasion of Human Rights Day. Available at: https://www.unaids.org/sites/ default/files/20191210_PS_UNAIDS_HR_Day_en.pdf. Accessed 8 May 2020.

UNHCR. (2018). Global Trends Forced Displacement in 2018. Available at https://www.unhcr.org/5d08d7ee7.pdf. Accessed 4 May 2020.

UNHCR. (2016). Global Trends - Forced Displacement in 2016. Available: http://www.unhcr.org/5943e8a34. Accessed 12 May 2020.

UNHCR. (2020). Figures at a Glance. Available at: https://www.unhcr. org/uk/figures-at-a-glance.html. Accessed 2 May 2020.

United Nations. (2015). International Migration Report 2015. Available at: http://www.un.org/en/development/desa/population/migration/ publications/migrationreport/docs/MigrationReport2015.pdf. Accessed 10 May 2020.

Williams, C. \& Graham, M. (2014). 'A World on the Move': Migration, Mobilities and Social Work; British Journal of Social Work (2014) 44, Supplement 1, i1-i17. doi: https://doi.org/10.1093/bjsw/bcu058

Wolffers, I., Verghis, S., and Marin, M (2003). Migration, Human Rights, and Health. The Lancet, 362(9400), 2019-20. https://doi. org/10.1016/S0140-6736(03)15026-X.

World Health Organization (2003). International Migration, Health and Human Rights. Available at: https://apps.who.int/iris/ bitstream/handle/10665/42793/9241562536.pdf? sequence $=1 \&$ isAllowed $=\mathrm{y}$. Accessed 20 May 2020.

Zetter, R. (2015). Protection in crisis: Forced migration and protection in a global era. Washington, D.C.: Migration Policy Institute.

Publisher's Note Springer Nature remains neutral with regard to jurisdictional claims in published maps and institutional affiliations. 